\title{
Teachers Commitment for the Administration of Public Senior Secondary Schools in Rivers State, Nigeria
}

\author{
Paul Tamaragaibi Elijah ${ }^{1^{*}} \quad$ John Okpako Enaohwo ${ }^{2}$ \\ ${ }^{1}$ Department of Mechanical Engineering, Nigeria Maritime University, Okerenkoko, Delta State, Nigeria \\ ${ }^{1,2}$ Department of Educational Management, University of Port Harcourt, Rivers State, Nigeria
}

\begin{abstract}
The study investigated teachers' commitment for the administration of public senior secondary schools in Rivers State. Two research questions and two hypotheses guided the study. Design adopted for this study was descriptive survey research design. Population of the study was 7425 teachers (3854 males and 3571 females) while 380 teachers (198 male and 182 female) were sampled for the study using multistage sampling technique. The instrument used for data collection was a 26 item questionnaire titled "Teachers Commitment for School Administration Questionnaire" (TCSAQ). The instrument was validated by three experts; two in Measurement and Evaluation and one in Educational Management. Cronbach Alpha was used to determine the internal consistency of the instrument with an index of 0.86 which was considered sufficient for the study. The research questions were answered using mean and rank order while z-test was used to test the hypotheses at 0.05 level of significance. Findings of the study showed a high level commitment to teachers work and students academic performance for the administration of public senior secondary schools in Rivers State. It was recommended that the government should endeavour to provide sufficient educational resources to promote teachers commitment.
\end{abstract}

Keywords: Teachers, Commitment, Administration, Secondary Schools, Rivers State

DOI: $10.7176 / \mathrm{JEP} / 12-16-07$

Publication date:June $30^{\text {th }} 2021$

\section{Introduction}

According to Thompson in Ssali (2011) "commitment is an engagement or obligation" that is to say, the state of being willing to give a lot of time to do something. In this study teachers' job commitment was looked at based on sense of belonging at school where teachers feel that they are part of and parcel of the school, excitement where teachers enjoy their job, confidence in management where teachers have trust in their leaders, teachers' syllabus coverage where teachers' cover what they are meant to teach in time, punctuality and regularity at work where teachers come on time and are present on all working days. According to Ssali (2011), people are committed to their job when they have sense of belonging, sense of excitement, punctual and regular to work; cooperation amongst staff and management.

According to Anwar et al. (2016), the strength of any profession depends up on the degree of commitment of its members. Teaching is no exception; this means that the strength of teaching profession depends up on the commitment of the teachers. Afolabi (2009) regarded teachers as the basic tools in education and curriculum implementations. The quality of any nation's education is determined by the qualities of the teachers and their attitude and commitment to the profession. Committed teachers have a tendency to perform the roles effectively as their job requires and to establish a good teacher-student relationship in accordance with the professional values. This approach facilitates student learning and development of terminal behaviors. However, in the clash of the career goals and values, and the goals and values of school, the importance of dedication and commitment increases. The basic goals and values of teaching profession effectively shape student behavior change in accordance with the principles of education sciences (Cagri 2013a; Elijah et al., 2019).

Aashiq (2017) opined that professional commitment of teachers has a pre-established significance in which employees establish the effective bond of agreement related to professional behavior. It ensures that a teacher should be out rightly committed to his work to acquire necessary knowledge and skills without any effective background. Professional commitment of teaching personnel means a feeling of dedication towards their profession. Committed teachers not only seek all round development of children but work for their own professional growth. Commitment of teachers has been identified as one of the most critical factors for the future success of education and schools. Professional commitment is the willingness to engage with the school community. It is a belief that reaches out beyond the four walls of the classroom and perhaps even extends beyond the boundary of the school. It is typically conceived as individuals' psychological bond to the organization including a sense of job involvement, loyalty and belief.

Quality education cannot be achieved without the efforts of dedicated and highly committed teachers. Committed teachers must inculcate and nurture values that will guide the subsequent use of the learning of both knowledge and skills in the wider world outside the classroom and lecture theatre. Educational scholars have advanced two strong reasons why teacher commitment should be emphasized in the fields of education. First, commitment was an internal force coming from within teachers themselves who had needs for greater 
responsibility, variety and challenge in their work as their level of participation in education had grown. Second, there were external forces directing both reform and development in education and seeking higher standards and greater accountability that were dependent upon each teacher's combined efforts, as well as the sustained efforts of the teachers within each school or institutional group.

Teacher commitment according to Mustafa (2017) is an internal force that derives teachers to invest more time and energy in keeping up involvement in the school. This willingness of promoting the school creates emotional link between teachers and the school which ultimately inspires teachers to seek ways to enhance teaching profession and establish an effective learning environment to allow students to reach their targets. Commitment to teaching is a crucial factor to contribute to the achievement of students. In addition, passion has a motivating factor; therefore, it is a significant need for high quality learning and teaching. Passion is seeking for the new, and experiencing new ideas. Passion is on the basis of effective teaching. Passion which is indispensable for learning and teaching facilitates learning thorough desire and enthusiasm it creates. Passionate teachers via creating effective learning environments endeavor to increase learning potentials of their students. This study explores the role of teacher commitment in student achievement and focuses on differences passionate teachers make, and points out the effects of passion on effective learning and teaching.

In relation to this, understanding the teachers' level of commitment is crucial because it reflects the teachers' involvement in school and the degree to which the teachers agree with the decision and make a great effort to achieve the decision goal (Yukl 2010; Ibrahim et al. 2013; Elijah et al., 2019). Anwar et al.(2016), classified areas of teachers' commitment into three namely: teachers' commitment towards community, students' academic achievement and their profession. Teachers are trusted professionals by the community to shoulder the responsibility of shaping the present generation for the future through the process of teaching and learning. Committed professionals should adopt various innovative method of teaching taking into consideration how best to learn and bring about the effective learning. This can happen only when teachers themselves show commitment to the profession to improve both guided as well as self-directed learning.

Globally, governments, voluntary agencies, non-governmental organizations and individuals commit significant resources towards building and developing teacher professionalism. The need for improving teachers' job satisfaction and commitment has been considered paramount since almost half of the new teachers leave the profession in the first five years (Akalewold as cited in Yalew 2014). According to Ukaigwe and Elijah (2020), some of the major factors that hindered teachers' commitment included: cumbersome curriculum and delay in salary payment and ways of dealing with these hindrances included prompt payment of salary among others. A committed teacher is focused and more involved in her/his profession. At times, it is presumed that teachers are committed and devoted to their profession, although this is not always the case. It has been sometimes noted that even though the line of work has been chosen voluntarily by teachers, commitment tend to decrease after sometime. Lower commitment affects the effectiveness of schools and causes teachers to be less successful in their professional performance or to leave the profession in extreme cases. Along with commitment towards the profession, teachers also need to be competent in their skills of teaching.

The professionalism and professional development have significance in affecting teachers' beliefs, attitudes, practices and student learning. In recent times this professional development cannot be complete without the adequate skills in information and communication technologies as it has been proven to remedy the problems and prospects of using digital devices in teaching and learning process (Elijah 2019; Amini-Philips \& Elijah 2019; Ohia \& Elijah, 2020). Learning how to teach, and working to become an excellent teacher is a long-term process that requires not only the development of very practical and complex skill under the guidance and supervision of experts, but also the acquisition of specific knowledge and the promotion of certain ethical values, attitudes and commitment (Calderhead \& Shorrock in Yalew 2014). According to Anwar et al. (2016), teachers' commitment to their profession entails: Reflecting on teaching pedagogy, maintaining accurate school records, communicating with families of students, growing and developing professionally, showing professionalism, demonstrating knowledge of content and pedagogy, setting instructional outcomes and managing classroom Procedures.

Professional commitment adds value to teaching and is successful when undertaken as an essential component of the teacher's routine, rather than an additional burden. This commitment is based on sound pedagogic approach including use of skills-based knowledge, code of professional conduct and within a professional organization. The teacher holds a position of professional status in the school hierarchy. The teacher performs the job of pathfinder who led students to valuable knowledge and understanding. In order to perform this function, teachers are required to be competent in their profession and flexible in their stance and approach. Effective teacher depends on the ability to put together the teaching skills, learning skills and subject matter as well as applying them imaginatively and creatively. Tweve (2011) documented teaching profession includes three fundamental characteristics. These characteristics were competence, performance, and conduct, which show the teacher's objectives, aptitudes, and standards, and directly influence the usefulness of teaching-learning process through the improvement of these characters. A professional teacher educates so that students learn 
concepts and apply them to their lives.

Delima (2015) in his study revealed the significant relationship between professional commitment and teachers' performance implies that teacher commitment is highly related to teachers' work performance which has a significant influence on students' achievement. Thus, teachers Professional Identity and Professional Commitment are important components that may lead to greatest degree of internal motivation, enthusiasm and job satisfaction which can considered as the important factors for the success of education in terms of performance.

According to Anwar et al. (2016), children need teachers who understand them and their needs with sensitivity. They need to be looked after by teachers who understand their instincts, learning needs and tendencies along with their capacities and abilities. By taking up the profession of teaching, the teacher is pledged to progress and development of learners. Teachers as basic tool in curriculum implementation remain a very crucial factor that influence students' experience and achievement, and continuing educational development. These are no longer achievable since teachers are accorded with little or no respect in the society due to insufficient fund, lack of motivation incentives, and delay in salary payment among others all these affects teachers' activities, causing psychological and emotional trauma which in turn affect his output (Afolabi 2009). According to Anneli \& Göran (2017), teacher commitment is a key factor for explaining how and why teachers care about their students' learning and well-being, and it is a well-known fact that teachers invest emotionally in their work and their students. Also, that teachers' commitment to their students' academic performance consists of four temporally related components namely moral, action/motivational, knowledge/self-confidence and reward/self-esteem.

Mustafa (2017) defines commitment as a psychological attachment to an organization in which people give their loyalty to its values and goals. Teacher commitment is the emotional bond teachers demonstrate toward their work. Teacher commitment has been recognized as one of the most critical factors in effective teaching. Thereby, teachers with high level of commitment can make a difference to the learning and achievement of their students. Committed teachers are affiliated with the school they work for and they invest their time and energy in promoting their school. Teacher commitment is associated with creating an effective learning environment in which students enhance their abilities for greater achievement. Committed teachers like working with their students and cares about their development. These teachers profoundly struggle for efficiency in teaching and learning through employing different approaches. Without love of profession, teaching cannot be conducted effectively. Teachers with high level of commitment are in love with teaching Garrison \& Liston (cited in Mustafa 2017).

According to Day in Mustafa (2017), committed teachers are passionate teachers who have deep subject matter knowledge, teaching techniques, ability to build empathy with their students; care about their students and see them as an important part of their job; always reflect on their goals and beliefs and motivate learners; are able to understand people around them and they are hopeful. According to Nwosu (2012), such committed teachers were likely also to develop sustained energy, efforts, work harder and demonstrate stronger affiliation to their schools, and show more desire to carry out the goals of teaching than teachers with low levels of commitment. More importantly, students of highly committed teachers are more likely to learn materials and develop positive attitude towards school than those of teachers with low levels of commitment. Professional commitment is needed in primary school. Commitment may also be a basic source of motivation since a person is more likely to perform best when he is committed to his job. It can be concluded that schools which seek to retain their teachers by building strong organizational commitment are in a better position to reap the benefits of a more dedicated, motivated, punctual and reliable teaching staff (Karluki et al.2014).

Committed teachers have a tendency to perform the roles effectively that their job requires and to establish a good teacher-student relationship in accordance with the professional values. This approach facilitates student learning and development of terminal behaviors. However, in the clash of the career goals and values, and the goals and values of school, the importance of dedication and commitment increases. The basic goals and values of teaching profession effectively shape student behavior change in accordance with the principles of education sciences (Cagri 2013b). Rots et al. (2010) identified teacher education variables such as faculty support, mentoring support and type of teacher education (i.e., elementary or secondary teaching). Chesnut \& Cullen (2014) focused on student-teacher personal factors, and identified emotional intelligence, self-efficacy and satisfaction with work expectations as important factors influencing commitment to teaching. Some researchers, focusing on the practicum, identified contextual and personal factors related to student-teachers' commitment to teaching. For example, Klassen et al. (2013) found that stress from school student behaviour and teacher workload was significantly and negatively correlated with commitment, and that self-efficacy was significantly and positively associated with commitment to teaching. Durksen \& Klassen (2012) identified the critical influence of personal resources (e.g. self-efficacy and resilience) and job resources (e.g. support from educational professionals and collaborative work climate) on student-teachers' commitment to teaching.

The purpose of this paper is therefore to investigate teachers' commitment for the administration of public 
senior secondary schools in Rivers State. Specifically, the study sought to:

1. determine the level of teachers' commitment to their profession in public secondary schools in Rivers State.

2. ascertain the level of teachers' commitment to the students' academic performance in public secondary schools in Rivers State.

The following research questions guided the study;

1. What is the level of teachers' commitment to their profession in public secondary schools in Rivers State?

2. What is the level of teachers' commitment to the students' academic performance in public secondary schools in Rivers State?

The following null hypotheses were tested at 0.05 level of significance:

1. There is no significant difference between the mean ratings of male and female teachers on their level of commitment to their profession in public secondary schools in Rivers State.

2. There is no significant difference between the mean ratings of male and female teachers on their level of commitment to students' academic performance in public secondary schools in Rivers State.

\section{Methodology}

The design adopted for this study was descriptive survey research design. Target population of the study consisted of 7425 teachers (3854 males and 3571 females) in the 268 Senior Secondary Schools in Rivers State. The sample size of the study was calculated using Taro Yamane formula and this gave a sample size of 380 teachers (198 male and 182 female). The study adopted multistage sampling technique in the selection of the elements of the study. In the selection process, the schools were first sampled using the Taro Yamane formula and the same formula was used to draw the required number of teachers from the selected schools. The instrument used for data collection was a 26 item questionnaire titled "Teachers Commitment for School Administration Questionnaire" (TCSAQ). The instrument was responded to on a four point modified likert scale of Very High Level (VHL), High Level (HL), Low Level (LL) and Very Low Level with weights of 4, 3, 2 and 1 respectively. The instrument was validated by three experts; two in Measurement and Evaluation and one in Educational Management. Cronbach Alpha was used to determine the internal consistency of the instrument with an index of 0.86 which was considered sufficient for the study. The instrument was administered by the researchers and two trained Research Assistant. The research questions were answered using mean and rank order while z-test was used to test the hypotheses at 0.05 level of significance.

\section{Results and Discussion}

Answer to Research Questions

Research Question One: What is the level of teachers' commitment to their profession for the administration of public senior secondary schools in Rivers State?

Table 1: Weighted mean and rank order scores of male and female teachers on their level of commitment to their teaching profession for the administration of public senior secondary schools in Rivers State

\begin{tabular}{|c|c|c|c|c|c|c|}
\hline $\mathbf{S} / \mathbf{N}$ & $\begin{array}{l}\text { Level of Teachers' commitment to their } \\
\text { Teaching Profession }\end{array}$ & $\begin{array}{l}\text { Male } \\
\text { Teachers } \\
198\end{array}$ & $\begin{array}{l}\text { Female } \\
\text { Teachers } \\
182\end{array}$ & $\begin{array}{l}\text { Mean } \\
\text { Set }\end{array}$ & Rank & Remark \\
\hline 1 & Work hard on my teaching approaches & 3.01 & 2.91 & 2.96 & $8^{\text {th }}$ & $\mathrm{HL}$ \\
\hline 2 & Prepared all the time for lessons ahead & 2.94 & 2.99 & 2.97 & $6^{\text {th }}$ & HL \\
\hline 3 & Observe teaching professional rules & 3.00 & 2.93 & 2.97 & $7^{\text {th }}$ & HL \\
\hline 4 & Committed to your teaching profession & 2.96 & 2.98 & 2.97 & $5^{\text {th }}$ & HL \\
\hline 5 & You develop a sense of school ownership & 3.13 & 2.93 & 3.03 & $3^{\text {rd }}$ & VHL \\
\hline 6 & You participate in school decision making & 3.02 & 3.18 & 3.10 & $1^{\text {st }}$ & VHL \\
\hline 7 & You Motivate students to learn & 3.01 & 2.89 & 2.95 & $9^{\text {th }}$ & HL \\
\hline 8 & Collaborate and cooperate with other school staff & 3.09 & 3.03 & 3.06 & $2^{\text {nd }}$ & VHL \\
\hline 9 & Encouraged to attend seminars and workshops & 2.99 & 2.98 & 2.99 & $4^{\text {th }}$ & HL \\
\hline 10 & $\begin{array}{l}\text { Discuss with other teachers on professional } \\
\text { development and seeking new knowledge }\end{array}$ & 2.92 & 2.95 & 2.93 & $10^{\text {th }}$ & HL \\
\hline 11 & $\begin{array}{l}\text { Keep school records intact (class register, diary, } \\
\text { etc.) }\end{array}$ & 2.90 & 2.81 & 2.86 & $12^{\text {th }}$ & HL \\
\hline 12 & Regular and punctual to school & 2.88 & 2.75 & 2.81 & $13^{\text {th }}$ & HL \\
\hline \multirow[t]{3}{*}{13} & Regular and punctual to classes & 2.94 & 2.88 & 2.91 & $11^{\text {th }}$ & $\mathrm{HL}$ \\
\hline & Aggregate & 38.79 & 38.23 & 38.51 & & \\
\hline & Grand Mean & 2.98 & 2.94 & 2.96 & & HL \\
\hline
\end{tabular}


In Table 1, it was revealed that all items 1-13 with mean scores of 2.96, 2.97, 2.97, 2.97, 3.03, 3.10, 2.95, $3.06,2.99,2.93,2.86,2.81$ and 2.91 were above the criterion mean score of 2.50 used for decision making and implied there was a high level in respect to the questionnaire items. However, items 5, 6 and 8 had higher mean scores which were above 3.00 and implied a very high level in respect to the items raised.

Research Question Two: What is the level of teachers' commitment to their students' academic performance for the administration of public senior secondary schools in Rivers State?

Table 2: Weighted mean and rank order scores of male and female teachers on their level of commitment to students' academic performance for the administration of public senior secondary schools in Rivers State

\begin{tabular}{|c|c|c|c|c|c|c|}
\hline $\mathbf{S} / \mathbf{N}$ & $\begin{array}{l}\text { Level of Teachers' commitment to Students' } \\
\text { Academic Performance }\end{array}$ & $\begin{array}{l}\text { Mean for } \\
198 \text { Male } \\
\text { Teachers }\end{array}$ & $\begin{array}{l}\text { Mean for } \\
182 \text { Female } \\
\text { Teachers }\end{array}$ & $\begin{array}{l}\text { Mean } \\
\text { Set }\end{array}$ & Rank & Remark \\
\hline 14 & $\begin{array}{l}\text { Use of appropriate teaching skills, techniques } \\
\text { and approaches during lesson delivery }\end{array}$ & 2.89 & 2.86 & 2.88 & $11^{\text {th }}$ & HL \\
\hline 15 & Careful preparation of scheme of work & 2.91 & 2.89 & 2.90 & $10^{\text {th }}$ & HL \\
\hline 16 & Proper writing of lesson plans and notes & 2.91 & 2.89 & 2.90 & $9^{\text {th }}$ & HL \\
\hline 17 & $\begin{array}{l}\text { Use of appropriate instructional materials during } \\
\text { lesson delivery }\end{array}$ & 2.95 & 2.88 & 2.91 & $8^{\text {th }}$ & HL \\
\hline 18 & Motivate students to learn & 3.05 & 3.04 & 3.04 & $2^{\text {nd }}$ & VHL \\
\hline 19 & Participate in students'extra-curricular activities & 2.93 & 2.91 & 2.92 & $6^{\text {th }}$ & HL \\
\hline 20 & Good class management during lesson delivery & 3.01 & 2.99 & 3.00 & $4^{\text {th }}$ & HL \\
\hline 21 & Regular and punctual to classes & 2.92 & 2.96 & 2.94 & $5^{\text {th }}$ & HL \\
\hline 22 & $\begin{array}{l}\text { Improvisation of instructional materials when } \\
\text { and where necessary }\end{array}$ & 2.95 & 2.88 & 2.92 & $7^{\text {th }}$ & HL \\
\hline 23 & Enforce strict disciplinary measures & 3.07 & 3.08 & 3.07 & $1^{\text {st }}$ & VHL \\
\hline 24 & $\begin{array}{l}\text { Appreciate and reward outstanding students in } \\
\text { class }\end{array}$ & 2.90 & 2.82 & 2.86 & $13^{\text {th }}$ & $\mathrm{HL}$ \\
\hline 25 & Cordial inter-personal relationship with students & 2.94 & 2.79 & 2.87 & $12^{\text {th }}$ & $\mathrm{HL}$ \\
\hline 26 & $\begin{array}{l}\text { Keep accurate school records of students (CA, } \\
\text { exam, etc.) }\end{array}$ & 2.99 & 3.01 & 3.00 & $3^{\text {rd }}$ & VHL \\
\hline & Aggregate & 38.41 & 38.01 & 38.21 & & \\
\hline & Grand Mean & 2.95 & 2.92 & 2.94 & & HL \\
\hline
\end{tabular}

Table 2 indicated that items 14-26 had mean scores of 2.88, 2.90, 2.90, 2.91, 3.04, 2.92, 3.00, 2.94, 2.92, $3.07,2.86,2.87$ and 3.00. All of these items were above the criterion mean score of 2.50 used for decision making and as such the items revealed a high level. However, items 18, 23 and 26 had mean scores above 3.00 and implied a very high level in respect to the question items raised.

\section{Test of Hypotheses}

Hypothesis One: There is no significant difference between the mean ratings of male and female teachers on their level of commitment to their profession for the administration of public senior secondary schools in Rivers State.

Table 3: z-test analysis of the mean score difference between male and female teachers on their level of commitment to their teaching profession for the administration of public senior secondary schools in Rivers State

\begin{tabular}{clrlccccc}
\hline S/N & \multicolumn{1}{c}{ Categories } & $\mathbf{n}$ & Mean & SD & Df & z-cal & z-crit & Remarks \\
\hline $\mathbf{1}$ & Male Teachers & 198 & 2.98 & 0.75 & \multirow{2}{*}{378} & \multirow{2}{*}{0.51} & \multirow{2}{*}{1.96} & Failed to \\
$\mathbf{2}$ & Female Teachers & 182 & 2.94 & 0.77 & & & \\
\hline \multicolumn{2}{r}{} & $\mathbf{n =}$ & $\mathbf{3 8 0}$ & & & & & \\
\hline
\end{tabular}

Table 3 revealed that male teachers have a mean and standard deviation scores of 2.98 and 0.75 respectively while female teachers have mean and standard deviation scores of 2.94 and 0.77 . The z-critical value was 1.96 at 0.05 alpha level and 378 degree of freedom while the z-calculated value was 0.51 and as such the null hypothesis failed to be rejected revealing that there was no significant difference in the mean ratings of male and female teachers on their level of commitment to their profession for the administration of public senior secondary schools in Rivers State.

Hypothesis Two: There is no significant difference between the mean ratings of male and female teachers on their level of commitment to students' academic performance for the administration of public senior secondary schools in Rivers State. 
Table 4: z-test analysis of the mean score difference between male and female teachers on their level of commitment to students' academic performance for the administration of public senior secondary schools in Rivers State

\begin{tabular}{clccccccc}
\hline S/N & \multicolumn{1}{c}{ Categories } & $\mathbf{n}$ & Mean & SD & Df & z-cal & z-crit & Remarks \\
\hline $\mathbf{1}$ & Male Teachers & 198 & 2.95 & 0.75 & \multirow{2}{*}{378} & \multirow{2}{*}{0.39} & \multirow{2}{*}{1.96} & Failed to \\
$\mathbf{2}$ & Female Teachers & 182 & 2.92 & 0.76 & & & & Reject \\
\hline \multicolumn{2}{r}{} & $\mathbf{n}=$ & $\mathbf{3 8 0}$ & & & &
\end{tabular}

Table 4 showed that male teachers have a mean and standard deviation scores of 2.95 and 0.75 respectively while female teachers have mean and standard deviation scores of 2.92 and 0.76 . The z-critical value was 1.96 at 0.05 alpha level and 378 degree of freedom while the z-calculated value was 0.39 and as such the hypothesis failed to be rejected implying that there was no significant difference in the mean ratings of male and female teachers on their level of commitment to students' academic performance for the administration of public senior secondary schools in Rivers State.

\section{Discussion of Findings}

Level of Teachers' Commitment towards their Teaching Profession for the Administration of Public Senior Secondary Schools in Rivers State

It was pointed out based on the responses of the respondents of the study that the findings of this study with regards analysis of research question one deduced that there is a high level of teachers' commitment to their profession in public secondary schools in Rivers State. This is because male and female teachers agree that they work hard and on their teaching approaches, prepare all the time for their lessons ahead, observe teaching professional rules, are committed to their teaching profession, develop a sense of school ownership, participate in school decision making, motivate students to learn, collaborate and cooperate with other school staff, are encouraged to attend seminars and workshops, discuss with one another on professional development and seeking new knowledge, keep school records intact (class register, diary, etc.), are regular and punctual to school. Similarly, the test of hypothesis proved that there was no significant difference in the mean scores of male and female teachers with regards the level of commitment of teachers to their profession in public secondary schools in Rivers State as the null hypothesis one was accepted in disfavour of the alternate hypothesis. The findings of this study are in agreement with the findings of Karluki et al. (2014) who opined that schools tend to retain teachers who are committed to their profession I terms of dedication, punctual and reliable. The findings of this study are also in line with the study of Yalew (2014) whose study found out that professionalism and professional development have significance in affecting teachers' beliefs, attitudes, practices and student learning. the findings of the study are also evident by the views of Anwar et al. (2016), teachers' commitment to their profession entails: Reflecting on teaching pedagogy, maintaining accurate school records, communicating with families of students, growing and developing professionally, showing professionalism, demonstrating knowledge of content and pedagogy, setting instructional outcomes and managing classroom Procedures.

Level of Teachers' Commitment towards Students' Academic Performance for the Administration of Public Senior Secondary Schools in Rivers State

In the study and with regards to the analysis of research question two, the study found that the teachers in public secondary schools in Rivers State have a high level of commitment to their students' academic performance. This is evident as the teachers agree that they use appropriate teaching skills, techniques and approaches during lesson delivery, carefully prepare their scheme of work, properly write lesson plans and notes, use appropriate instructional materials during lesson delivery, motivate their students to learn, participate in students extracurricular activities, they use good class management skills during lesson delivery, regular and on time to classes, enforce strict disciplinary measures, appreciate and reward outstanding students in class, cordial inter-personal relationship with students and keep accurate school records of students.

Furthermore, the test of hypothesis two proved that there was no significant difference in the mean scores of male and female teachers with regards the level of commitment of teachers to their students' academic performance in public secondary schools in Rivers State as the null hypothesis two was accepted in disfavour of the alternate hypothesis. The finding of this study is in line with the study of Mustafa (2017) who opined that committed teachers like working with their students and cares about their development. According to him, these teachers, profoundly struggle for efficiency in teaching and learning through employing different approaches. The finding of this study is also in accordance with the opinions of Nwosu (2012) that committed teachers are likely also to develop sustained energy and efforts.

\section{Conclusions}

Based on the findings of the study, it was concluded that:

There was a high level of teacher's commitment to their profession in terms of teaching approach, preparation of lessons and participation in teaching and learning as well as to students academic performance in terms of 
improvisation of instructional materials, discipline and interpersonal relations for the administration of public senior secondary schools in Rivers State.

\section{Recommendations}

The following recommendations were made in line with the findings of the study:

1. The government should build new and befitting school structures like library, laboratories, workshops, canteens, convenience to allow for meaningful teaching and learning environment as well as smooth administration of the school for improved student's performance.

2. School administrators should design a policy framework that allows teachers to give their input in the administration of the school for their benefit as well as that of other school personnel.

\section{References}

Amini-Philips, C. \& Elijah, P. T. (2019). Impact of information and communication technologies (ICTS) on higher education in Nigeria in the 21st century. Journal of Humanities and Social Science, 24(10), 837-845. DOI: $10.9790 / 0837-2410110107$

Aashiq, A. T. (2017). Professional commitment of government and private school teachers with special reference to their rural urban dichotomy. International Journal of Humanities Social Sciences and Education, 4(6), 95-103

Afolabi, F. (2009). Teachers' attitude and gender factor as determinant of pupils' performance in primary science. An International Multi-Disciplinary Journal, 3(1), 326-332

Anneli, F. \& Göran, F. (2017). Four components that sustain teachers' commitment to students: A relational and temporal model. Reflective Practice, 18(5), 641-654

Anwar, A. H., Sisay, A.W. \& Tamirat, Z. T. (2016). Teachers professional commitment towards students learning, their profession and the community in eastern Ethiopian secondary schools. Journal of Teacher Education and Educators, 5(3), 289-314

Cagri, T. M. (2013a). Commitment to school and students. International Journal of Academic Research in Business and Social science, 3(1), 336-340

Cagri, T.M. (2013b). A passionate teacher: Teacher commitment and dedication to student learning. International Journal of Academic Research in Progressive Education and Development, 2(1), 437-442

Chesnut, S. R. \& Cullen, T. A. (2014). Effects of self-efficacy, emotional intelligence, and perceptions of future work environment on pre-service teacher commitment. The Teacher Educator, 49(2), 116-132

Delima, V. T. (2015). Professional identity, professional commitment and teachers' performance. Int. J. Novel Res. Edu. Learning, 2(4), 1-12

Durksen, T. L. \& Klassen, R. M. (2012). Pre-service teachers' weekly commitment and engagement during a final training placement: A longitudinal mixed methods study. Educational and Child Psychology, 29(4), $32-46$

Elijah, P. T. (2019). Problems and prospects of using digital devices for learning engineering drawing in public universities in Delta state. Trends in Educational Studies, 11(3), 220-231

Elijah, P. T., Paul, F. Y. and Elijah, D. (2019). Lecturer Quality as Predictor of Academic Performance of Undergraduate Engineering Students in Public Universities in Delta state. Nigerian Journal of Educational Planning and Administration, 19(1), 349-366

Ibrahim, M. S., Ghavifekr, S., Ling, S., Siraj, S. and Azeez, M. I. K. (2013). Can transformational leadership influence on teachers' commitment towards organization, teaching profession, and student learning? A quantitative analysis. Asia Pacific Education Review, 15(2), 177-190

Karluki, K.A., Ndirangu, M., Song, K.A. \& Oako, M.E. (2014). Secondary school teachers' perceptions of the factors that influence their morale and commitment to work: A Case of Nakuru District. International Journal of Innovation and Applied Studies, 9(4), 1589-1597

Klassen, R., Wilson, E., Siu, A. F. Y., Hannok, W., Wong, M. W., Wongsri, N., Sonthisap, P., Pibulchol, C., Buranachaitavee, Y. \& Jansem, A. (2013). Pre-service teachers' work stress, self-efficacy, and occupational commitment in four countries. European Journal of Psychology of Education, 28, 1289-1309

Mustafa, A. (2017). The effects of teacher commitment on student achievement: A case study in Iraq. International Journal of Academic Research in Business and Social Sciences, 7(11), 417-426

Nwosu, C.C. (2012). Attitude and work commitment of teachers. Journal of Behavioural Science and Education, 6(1), 62-74

Ohia, A.N. and Elijah, P.T. (2020). Lecturers' Technological Integration for Classroom Management in Public Universities in Delta State. Journal of Science, Technology, Mathematics and Education, 16(4), 159-167.

Rots, I., Aelterman, A., Devos, G. \& Vlerick, P. (2010). Teacher education and the choice to enter the teaching profession: A prospective study. Teaching and Teacher Education, 26(8), 1619-1629

Ssali, G. (2011). Rewards and job commitment of primary school teachers in Mityana District. Department of 
Educational Management, Makerere University

Tweve, T. J. (2011). Teacher professionalism and professional abuse towards education development in Tanzania. 4th community of Practice for learner-centred education, 189-192

Ukaigwe, P.C. \& Elijah, P.T. (2020). Impediments to Teachers Commitment for the Administration of Public Senior Secondary Schools in Rivers State, Nigeria. African Journal of Educational Management, 21(1), $159-175$.

Yalew, E., Getachew, K. \& Tadesse, M. (2014). The status, challenges and prospects of teacher professionalism in the Amhara Region. Implication for Quality Education, Proceedings of the International Conference on Quality Education, Addis Ababa, Ethiopia. Apple Printing Press:

Yukl, G. A. (2010). Leadership in organizations (7th ed.). Upper Saddle River, NJ: Prentice Hall

\section{Biodata}

Paul Tamaragaibi Elijah, FCIA, NSE, NIMechE, NIM who hails from Ayakoromo, Burutu LGA in Delta State was born 12th May, 1985 into the family of Archbishop Dr. and bishop Dr. (Mrs.) Gbolo Elijah Temekoga (Presiding bishop of Church of the Living God). He holds the following degrees: B.Eng Mechanical Engineering, earned in 2012 from University of Port Harcourt, Port Harcourt, Rivers State, Nigeria; PGD Education earned in 2014 from National Teachers' Institute of Nigeria in collaboration with National Open University of Nigeria; Masters of Engineering Management earned in 2016 from University of Port Harcourt, Port Harcourt, Rivers State, Nigeria; M.Eng Production and Maintenance Engineering earned in 2019 from University of Port Harcourt, Port Harcourt, Rivers State, Nigeria; and M.Ed Educational Management and Planning earned in 2021 from University of Port Harcourt, Port Harcourt, Rivers State, Nigeria. He is currently a doctoral student in Applied Mechanics and Design at the department of Mechanical Engineering, University of Port Harcourt.

$\mathrm{He}$ is a distinguished lecturer of mechanical engineering at Nigeria Maritime University. He has held several responsibilities (both academic and administrative) in the University and is currently the coordinator of quality assurance and quality control in the institution. He is involved in capacity building of quality assurance practitioners and a seasoned consultant to both engineering company and educational institutions. He has published articles in several national and international renowned journals in the various fields of Mechanical Engineering and Educational Management. He has also presented some of his works in conferences such as; the Nigerian Institution of Mechanical Engineers (NIMechE); International Conference on Quality Assurance in Higher Education in Africa (ICQAHEA) in conjunction with the African Quality Assurance Network (AfriQAN); Nigerian Academy of Education; Nigerian Association for Educational Administration and Planning \& the Commonwealth Council for Educational Administration and Management Affiliate; just to mention a few. He is a member of several academic, religious and social organizations both nationally and internationally. 